SILVA, CQ; RODRIGUES, R; BENTO, CS; PIMENTA, S. 2017. Heterosis and combining ability for ornamental chili pepper. Horticultura Brasileira 35: 349-357. DOI - http://dx.doi.org/10.1590/S0102-053620170306

\title{
Heterosis and combining ability for ornamental chili pepper
}

\section{Camila Q Silva; Rosana Rodrigues; Cíntia S Bento; Samy Pimenta}

Universidade Estadual do Norte Fluminense Darcy Ribeiro (UENF), Campos dos Goytacazes-RJ, Brasil; mylacqs@gmail.com; rosana@ uenf.br; cintia_bento@yahoo.com.br; samypimenta@bol.com.br

\begin{abstract}
Ornamental use of Capsicum genus chili peppers has expanded due to easy seed propagation, short germination period, diversified fruit colors and harmony of potted plants. The ornamental plant sector requires cultivars adapted to different cultivation conditions in pots and gardens. Breeding programs can use heterosis and combining ability information, aiming to commercially explore hybrids or develop populations for lineage selection with desirable characteristics. However, the ornamental chili pepper field lacks studies with this data. In this study, combining ability of $C$. annuum accessions was determined for ornamental purposes and hybrid combinations were identified based on heterosis values. Fifteen hybrids were obtained from diallel crosses of six genotypes of $C$. annuиm, from March to September 2014, under greenhouse conditions, grown in five-liter pots in experimental design of randomized blocks with 10 repetitions and one plant per plot. Morpho-agronomic characterization was conducted based on eight quantitative descriptors: plant height (before and after fruiting); canopy diameter; days to flourishing; days to fruiting; fruit length and diameter, and number of fruits per plant. Both additive and dominance effects play important role in controlling the studied characters, indicating hybrid exploitation as well as development of superior lineages from the progress of segregating generations. Negative heterosis values resulted in reduction in height, time for flourishing and fruiting, as well as fruit diameter and length, which are desirable for ornamental Capsicum breeding program. Considering an ideotype for ornamental chili pepper cultivars, the hybrids UENF 1626 x UENF 1750, UENF 1750 x UENF 2030 and UENF 1626 x UENF 2030 can be recommended for cultivation with ornamental purposes.
\end{abstract}

Keywords: Capsicum annuum, ornamental breeding, ideotype, diallel analysis.

\section{RESUMO}

\section{Heterose e capacidade combinatória em pimentas ornamentais}

O uso ornamental das pimentas do gênero Capsicum tem se expandido em função da fácil propagação das sementes, do curto espaço de tempo de germinação, da coloração diversificada de seus frutos e da harmonia das plantas em vasos. O setor de plantas ornamentais demanda cultivares adaptadas a diversas condições de cultivo em vasos e jardins. Os programas de melhoramento podem utilizar as informações sobre heterose e capacidade combinatória, a fim de explorar comercialmente híbridos ou desenvolver populações de trabalho para seleção de linhagens com as características desejáveis. Em pimentas para uso ornamental ainda são escassos trabalhos com estas informações. Neste trabalho determinou-se a capacidade combinatória de acessos de C. annuum para fins ornamentais e identificaram-se combinações híbridas superiores com base em seus valores de heterose. Quinze híbridos foram obtidos a partir de cruzamentos dialélicos entre seis acessos de C. annuum, de março a setembro de 2014 , em casa de vegetação, cultivados em vasos de cinco litros em delineamento experimental de blocos ao acaso, com 10 repetições e uma planta por parcela. A caracterização morfoagronômica foi realizada com base em oito descritores quantitativos: altura de planta (antes e depois da fase de frutificação); diâmetro de copa; dias para o florescimento; dias para frutificação; comprimento e diâmetro do fruto, e número de frutos por planta. Efeitos aditivos e de dominância foram importantes no controle dos caracteres estudados neste trabalhando indicando a exploração de híbridos assim como o desenvolvimento de linhagens superiores a partir do avanço das gerações segregantes. Valores de heterose negativos resultaram na redução da altura, no tempo para florescimento e frutificação, diâmetro e comprimento do fruto, desejáveis para o programa de melhoramento de Capsicum ornamental. Considerando um ideótipo para cultivar de pimenta ornamental se destacaram os híbridos UENF 1626 x UENF 1750 , UENF 1750 x UENF 2030 e UENF 1626 x UENF 2030.

Palavras-chave: Capsicum annuum, melhoramento de ornamentais, ideótipo, análise dialélica.

\section{Received on December 7, 2015; accepted on June 10, 2016}

$\mathrm{T}$ he production of flowers and ornamental plants in Brazil has as main destination, the domestic market, being more than $90 \%$ of the financial volume marketed by producers. Consumption in Brazil still has much to evolve, especially when compared to consumption in more mature markets, such as the European (Neves et al., 2015). To the expansion and valorization of this market segment, new products are required to supply the demand and attract potential supporters of the ornamental plant consumption.

Chili peppers (Capsicum annuum) for ornamental purpose has gained scope representing new options such as cultivation of potted plants in gardens and also as cut foliage. The diverse application forms are mainly related to fruit, foliage and plant height characteristics (Carvalho et al., 2006; Rêgo et al., 2012). The growing demand in ornamental market for chili pepper 
cultivars associated to high variability of Capsicum genus plants has recently provided establishment of chili pepper breeding programs aiming to obtain new cultivars (Rêgo et al., 2013).

Capsicum annuum is the most studied species of the genus, including in genetic and breeding terms, and several investigations report results of diallelic crossings. Patil \& Bhalekar (2012) highlighted the importance of obtaining and applying hybrids to increase fruit production and pepper earliness $(C$. annuиm). Pandey et al. (2012) identified five promising hybrids in terms of fruit production, by evaluating $C$. annuиm parental and hybrids. Hasanuzzaman et al. (2013), evaluating heterosis in local varieties of Capsicum annuиm in Bangladesh, found high heterosis values and suggested the use of six studied lineages for further hybrid development. Nascimento et al. (2014) observed that non-additive effects, epistasis and/or dominance were the most relevant to control fruit production per plant and days until fruiting, among other traits, in a complete diallel, with reciprocals, in Capsicum annuum, demonstrating complexity in the genetic control of these characters. In addition, in this regard, the authors recommend hybridization as a strategy for obtaining ornamental chili peppers.

Nevertheless, data from genetic control studies of Capsicum plants specifically for ornamental purposes are limited in literature, having just a few works about it and those works belong the Capsicum working group of Paraíba Federal University (UFPB), resulting in a lack of information that lead to a low application of Capsicum genotypes of ornamental potential and a reduced number of cultivars developed to serve this niche market.

This study discloses results of combining ability of Capsicum annuum accessions and identifies superior hybrid combinations that are potentially useful as new cultivars of ornamental chili pepper.

\section{MATERIAL AND METHODS}

Parental genotypes and obtainment of $F_{1}$ hybrids

Six accessions of Capsicum annuum from germplasm bank of the Universidade Estadual do Norte Fluminense Darcy Ribeiro (UENF) (Table 1) were selected based on preliminary studies for indication of genitors with potential ornamental use (Silva et al., 2015) and crossed in a complete diallelic mating system without reciprocal crosses to obtain $\mathrm{F}_{1}$ generation.

In hybridization stage, the plants were cultivated in greenhouse (structure $11.5 \mathrm{~m}$ long $\mathrm{x} 7 \mathrm{~m}$ wide, covered with plastic additive against $U V$ rays of $150 \mu$ and $70 \%$ shade), located in the Unidade de Apoio à Pesquisa of UENF, in Campos dos Goytacazes, Rio de Janeiro State, Brazil, from June to December 2013 and the average results for relative humidity and temperature were $69 \%$ and $30^{\circ} \mathrm{C}$, respectively, recorded throughout the trial period. Seedlings were produced in polystyrene trays with 128 cells containing commercial subtract and transplanting was conducted when the seedlings had four to six pairs of definitive leaves, by transferring them into 5-liter plastic pots filled (spacing $1.0 \times 0.5 \mathrm{~m}$ ) with mixture of soil, sand and cattle manure in the proportion 1:1:1 and $5 \mathrm{~g} /$ pot of NPK formulation (4-14$8)$, keeping one plant per pot.

Cultural practices used in culture were manual removal of weeds, maintenance fertilization, prevention and control of pests and diseases and the irrigation was done manually.

Crossings were managed by sampling newly opened floral buds of each male parent for pollen withdrawal. Pollen of each parent was stored in refrigerator inside of properly identified amber glasses containing silica gel. Female parent floral buds were emasculated in the morning before anthesis using tweezers. Pollination was carried out by placing pollen grains of each male parent on each emasculated flower stigma. Woolen yarns of different colors were used to identify fruits derived from each crossing. Hybridization efficiency (HE) percentage was calculated based on the following expression:

$\mathrm{HE}=$ (number of effective crossings/ number of performed crossings) x 100

Evaluation of genitors and hybrids

The experiment was conducted from March to September 2014 under the same greenhouse conditions used for the $\mathrm{F}_{1}$ hybrids obtainment in a completely randomized block design, with ten replications and one plant per plot. Seedling production, transplanting period and cultural treatments were the same adopted for plant cultivation in the hybridization period.

Morpho-agronomic characterization was accomplished considering different parts of plants, according to Capsicum genus descriptors proposed by IPGRI (1995) and some modifications proposed by Silva et al. (2015) for prompt data acquisition.

Eight quantitative descriptors were analyzed with basis on average values of each access: plant height (HGT) $(\mathrm{cm})$, measured from the plant base to the highest point of the canopy, using measurement tape, before and afterwards fruiting, HGT1 and HGT2, respectively; greater canopy diameter (GCD) $(\mathrm{cm})$ measured simultaneously to plant height with the aid of a measurement tape. Number of days to flourishing (DFL) was computed counting from sowing to the moment in which at least half of the plants were with a minimum of one open flower.

The following fruit characteristics were evaluated: total number of fruits (TNF) (sum of ripe fruits harvested during crop cycle); days to fruiting (DFR) (counting from transplanting date to the moment in which $50 \%$ of the plants had ripe fruits in the first and second bifurcation); fruit length (LOF) (mm) and fruit diameter (DOF) $(\mathrm{mm})$; LOF and DOF were evaluated in laboratory, using average of five ripe fruits randomly obtained; the measurements were done with digital caliper.

Statistical and genetic analysis of data

Analysis of variance (ANOVA) with basis on the averages of each treatment was conducted for quantitative data. The means were grouped by Scott-Knott test $(p<0.05)$. In order to conduct diallel analysis, combination general capacity (GCA) and combination specific capacity (SCA) were determined in accordance with the model proposed by Griffing and conforming to method 
2, which includes genitors and $F_{1}$ hybrids, and considering model 1 (fixed effect genotypes and random effect error). Heterosis calculation was carried out based on the average of parents according to formula: $\mathrm{Hmp}=\left(\mathrm{F}_{1}-\mathrm{MP} /\right.$ MP) $x 100$, wherein $\mathrm{MP}=\left(\mathrm{P}_{1}+\mathrm{P}_{2}\right) / 2$. All the analyses were performed using Genes software (Cruz, 2016).

\section{RESULTS AND DISCUSSION}

\section{Hybridization efficiency}

Three hundred and seventy four pollinations were performed and the crossing success rate varied from 42 to $95 \%$, resulting in 11 to 48 fruits, in accordance with the number of pollinations conducted for hybrid combinations, and the number of produced seeds for some crossings was above 500 (Table 1). Cardoso (2005), when studying pollination with zucchini, suggested that the increment in number of seeds per plant is explained by the use of high quantity of pollen. In this study, an increased number of crossings for a determined hybrid combination contributed to a greater harvested fruit number. Except for four hybrid combinations (UENF $1626 \mathrm{x}$ UENF 1750; UENF 1626 x UENF 1627; UENF $1627 \times$ UENF 2030, and UENF 1627 x UENF 1632) the others

Table 1. Hybrid combinations, number of crosses performed, number of fruits, crossing success rate and number of seeds produced in crosses between six parents of Capsicum annuum. Campos dos Goytacazes, UENF, 2014.

\begin{tabular}{lcccc}
\hline $\begin{array}{l}\text { Identification } \\
\text { of crosses }\end{array}$ & $\begin{array}{c}\text { Number } \\
\text { of crosses }\end{array}$ & $\begin{array}{c}\text { Number of } \\
\text { fruits }\end{array}$ & $\begin{array}{c}\text { Crossing success } \\
\text { rate (\%) }\end{array}$ & $\begin{array}{c}\text { Number of } \\
\text { seeds }\end{array}$ \\
\hline $1626 \times 1750$ & 26 & 11 & 42.30 & 107 \\
$1626 \times 1627$ & 21 & 15 & 71.43 & 341 \\
$1626 \times 2030$ & 18 & 17 & 94.44 & 448 \\
$1626 \times 1632$ & 22 & 19 & 86.36 & 444 \\
$1626 \times 1623$ & 20 & 19 & 95.00 & 425 \\
$1627 \times 2030$ & 18 & 13 & 72.22 & 413 \\
$1627 \times 1632$ & 20 & 15 & 75.00 & 497 \\
$1627 \times 1623$ & 17 & 15 & 88.24 & 547 \\
$1632 \times 1623$ & 58 & 48 & 82.21 & 878 \\
$1750 \times 1627$ & 22 & 19 & 86.36 & 551 \\
$1750 \times 2030$ & 23 & 20 & 91.30 & 541 \\
$1750 \times 1632$ & 23 & 21 & 91.30 & 843 \\
$1750 \times 1623$ & 21 & 19 & 90.48 & 633 \\
$2030 \times 1623$ & 36 & 34 & 94.44 & 1051 \\
$2030 \times 1632$ & 29 & 26 & 89.65 & 915 \\
\hline
\end{tabular}

had success rate above $80 \%$, supporting data from studies of manual pollination in pepper conducted by Godoy et al. (2006), which achieved values from 80 to $94 \%$ success of pollinated flowers.

\section{ANOVA and diallelic analysis}

Among 15 hybrids, only the combination UENF 1632 x UENF 1623 did not obtain seed germination, resulting in 14 evaluated hybrids. The variance analysis evidenced highly significant difference $(p<0.01)$ for all evaluated characters concerning treatment variation source (Table 2). The coefficient of variation (CV) values were between proposed limits for Capsicum genus according to Silva et al. (2011), who studied classification criteria of CVs for six variables in peppers, and also in the same magnitude of $\mathrm{CV}$ values

Table 2. Estimates of general and specific combining ability (GCA and SCA), and mean square effects for eight agronomic traits in diallel crosses from six chili peppers parents, according to Method 2, Model 1 (Griffing, 1956). Campos dos Goytacazes, UENF, 2014.

\begin{tabular}{|c|c|c|c|c|c|c|c|c|c|}
\hline \multirow{2}{*}{$\begin{array}{l}\text { Source of } \\
\text { variation }\end{array}$} & \multicolumn{9}{|c|}{ Mean square } \\
\hline & DF & $\begin{array}{l}\text { HGT1 } \\
(\mathrm{cm})^{1}\end{array}$ & $\begin{array}{l}\text { HGT2 } \\
\text { (cm) }\end{array}$ & $\begin{array}{l}\text { GCD } \\
(\mathrm{cm})\end{array}$ & DFL & DFR & LOF (mm) & DOF (mm) & TNF \\
\hline Treatment & 20 & $27.71^{* *}$ & $148.65^{* *}$ & $21.60 * *$ & $44.58^{* *}$ & $77.49 * *$ & $1320.53 * *$ & $86.37 * *$ & $7269.99 * *$ \\
\hline GCA & 5 & $69.58 * *$ & $476.14^{* *}$ & $49.36^{* *}$ & $136.00 * *$ & $171.06 * *$ & $4708.75^{* *}$ & $329.94 * *$ & $26307.33^{* *}$ \\
\hline SCA & 15 & $13.75^{* *}$ & $39.49 * *$ & $12.35^{* *}$ & $14.11 * *$ & $46.30 * *$ & $191.12 * *$ & $5.19 * *$ & $924.21 * *$ \\
\hline \multirow[t]{2}{*}{ Residue } & 180 & 2.91 & 19.18 & 22.14 & 4.59 & 11.90 & 24.40 & 1.38 & 318.38 \\
\hline & \multicolumn{9}{|c|}{ Mean Squares of effect } \\
\hline GCA & & 3.06 & 142.02 & 1.55 & 11.60 & 18.74 & 13865.31 & 68.04 & 432725.37 \\
\hline SCA & & 2.61 & 24.88 & 7.48 & 2.89 & 30.16 & 493.64 & 0.38 & 12515.19 \\
\hline Residue & & 0.09 & 4.09 & 5.45 & 0.23 & 1.57 & 6.61 & 0.02 & 1126.26 \\
\hline
\end{tabular}

${ }^{1} \mathrm{HGT} 1,2=$ plant height before and afterwards fruiting; $\mathrm{GCD}=$ canopy diameter; $\mathrm{DFL}=$ number of days to flourishing; $\mathrm{DFR}=\mathrm{days}$ to fruiting. $\mathrm{LOF}=$ fruit length; $\mathrm{DOF}=$ fruit diameter; $\mathrm{TNF}=$ total number of fruits. ${ }^{* *} \mathrm{p} \leq 0.01$ by $\mathrm{F}$ test. 
Table 3. Estimates of general combining ability ( $\mathrm{g} i)$ effects for eight agronomic traits evaluated in six genotypes of Capsicum annumm. Campos dos Goytacazes, UENF, 2014.

\begin{tabular}{lrrrrrrrr}
\hline Genotypes & $\begin{array}{c}\text { HGT1 } \\
(\mathbf{c m})^{\mathbf{1}}\end{array}$ & $\begin{array}{c}\text { HGT2 } \\
(\mathbf{c m})\end{array}$ & $\begin{array}{c}\text { GCD } \\
(\mathbf{c m})\end{array}$ & DFL & DFR & $\begin{array}{c}\text { LOF } \\
(\mathbf{m m})\end{array}$ & $\begin{array}{r}\text { DOF } \\
(\mathbf{m m})\end{array}$ & TNF \\
\hline 1626 & -0.98 & -2.60 & -0.63 & 1.24 & 1.08 & -9.24 & -0.85 & 10.94 \\
1750 & 0.31 & -0.14 & 0.75 & 0.74 & 1.08 & -9.71 & -1.58 & 27.63 \\
1627 & 0.95 & 1.34 & 0.16 & 1.24 & 1.60 & 7.66 & -0.62 & -3.06 \\
2030 & 0.60 & -0.03 & -0.42 & -0.45 & -1.12 & 6.70 & -1.86 & 2.07 \\
1632 & -1.35 & -2.49 & -0.91 & -0.73 & -0.53 & 2.86 & 3.31 & -23.33 \\
1623 & 0.46 & 3.88 & 1.04 & -2.04 & -2.09 & 1.72 & 1.60 & -14.26 \\
\hline $\mathrm{DP}\left(\mathrm{G}_{\mathrm{i}}-\mathrm{G}_{\mathrm{i}}\right)$ & 0.27 & 0.69 & 0.74 & 0.34 & 0.55 & 0.78 & 0.18 & 2.82 \\
\hline
\end{tabular}

${ }^{1} \mathrm{HGT} 1,2=$ plant height before and afterwards fruiting; $\mathrm{GCD}=$ canopy diameter; $\mathrm{DFL}=$ number of days to flourishing; $\mathrm{DFR}=$ days to fruiting. $\mathrm{LOF}=$ fruit length; $\mathrm{DOF}=$ fruit diameter; $\mathrm{TNF}=$ total number of fruits.

found by Rodrigues et al. (2012) in studies with Capsicum baccatum.

There was a highly significant difference for all characteristics in terms of GCA and SCA, indicating that additive and dominance effects are important to control the studied traits. Therefore, there is a possibility of hybrid exploitation as well as development of superior lineages from the progress of segregating generations. However, estimations of genitor effects and $F_{1}$ hybrid mean squares, in accordance with Method 2 and model 1 from Griffing, evidenced predominance of additive effects for almost every evaluated characteristic, except for GCD and DFR that had greater influence of dominance effects (Table 2). In general, these results indicated predominance of GCA effects in relation to SCA ones, which means predominance of additive effects on height characteristic (before and afterwards fruiting); days to flourishing; fruit length and diameter, and number of fruits per plant. Rodrigues et al. (2012) and Medeiros et al. (2014) identified additive and non-additive effects for characteristics of canopy diameter; days to fruiting; number of fruits per plant, and fruit length and diameter when evaluating similar traits in Capsicum baccatum under greenhouse and field conditions, respectively. However, these authors observed that additive effects were predominant for plant height. Similarly, Nascimento et al. (2014), when evaluating Capsicum annuum genetic effects on fruit production and quality, verified that additive effects are more important in regarding fruit length and diameter, while non-additive effects were more significant for the days to fruiting.

Negative values of GCA estimation (ĝi) for plant height were expressed in the parental UENF 1626 and UENF 1632 in both measurements (HET1 -0.98 and -1.35 ; HET2 -2.60 and -2.49 , respectively) (Table 3 ). When used in crossings, these genotypes contribute to small-sized plant obtainment, generating individuals for potted plant market with indoor decorative purposes. Silva et al. (2015), whose research studied parental selection for ornamental purposes, and Carvalho et al. (2006), who discussed what characteristics grant ornamental trait to peppers, both observed smallsized plant preference by consumers for pot cultivation and stated that these traits are related to growth trend. From the other side, values of gi observed for showed that they could contribute to increasing plant height, subsequently to fruiting (HET2). Another desirable usage for chili pepper is garden cultivation, in which higher plants can be used.

Regarding GCD, UENF 1623 contributed with positive values of g $\mathrm{i}$ (1.04) (Table 3), favoring excellent canopy diameters, which means that this genotype when used in crossings might produce more visually attractive hybrids due to their bigger canopy (larger foliage). In regards of earliness, lower values of gi for DFL and DFR were UENF 1627 and UENF 1623 genitors achieved by genitor UENF 1623 (-2.04 and -2.09 , respectively). Concerning LOF and DOF, in general, negative values of ĝi are required for ornamental purpose, since it favors small-size fruit production but in higher number. In regards of TNF, positive values of $\hat{\mathrm{g} i}$ are preferred. Genotypes UENF 1626 and UENF 1750 contributed with lower values of gi for LOF and DOF (-9.24 and -9.71) and (-0.85 and -1.58), respectively and with positive values of ĝi for TNF (10.94 and 27.63). Such characteristics were also approached by Rêgo et al. (2010), with chili peppers ( $C$. baccatum), and Silva et al. (2015) with Capsicum spp. These studies described a negative correlation between fruit size and number of fruits per plant, indicating that lower values of fruit size enable greater production of fruits per plant, an association that grants better attractiveness and harmony in ornamental ambiance.

Effect of SCA estimations (Ŝii and $\hat{S} i j$ ) (Table 4) indicated the effect of hybrid combination between genitors and its interpretation is according its relation with GCA values of its parents (Griffing). Ornamental in-pot cultivation for indoor decoration requires low plant height (Carvalho et al., 2006; Neitzke et al., 2010; Silva et al., 2015). Regarding the character HET1, 11 hybrid combinations had satisfactory results, with negative values for the following characters: UENF 1626 x UENF 1627 (-1.74); UENF 1626 x UENF 2030 $(-1.20)$; UENF $1626 \times$ x UENF 1632 $(-0.85)$; UENF $1626 \times$ x UENF 1623 (-0.36); UENF 1750 x UENF 1627 (-0.13); UENF 1750 x UENF 1632 (-0.63); UENF $1750 \times$ x UENF 1623 (-0.40); UENF $1627 \times$ UENF 2030 (-0.57); UENF 1627 x UENF 1623 (-1.58); UENF 2030 x UENF 1632 (-1.07) and UENF 1632 x UENF 1623 (-0.56). However, these results were not expected for UENF $1750 \mathrm{x}$ UENF 1627, UENF 1750 x UENF 1623, UENF 1627 x UENF 2030 and UENF $1627 x$ UENF 1623, since none of their parents presented effects of negative GCA for this characteristic, evidencing that these hybrid combinations presented better results in relation to SCA of their parents. Some combinations stood out 
Table 4. Estimates of specific combining ability (Ŝii and $\hat{\mathrm{S} i j}$ ) effects for eight traits evaluated in six genotypes of $C$. annuum. Campos dos Goytacazes, UENF, 2014.

\begin{tabular}{|c|c|c|c|c|c|c|c|c|}
\hline 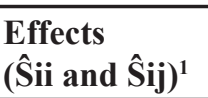 & $\begin{array}{l}\text { HGT1 } \\
(\mathrm{cm})^{2}\end{array}$ & $\begin{array}{c}\text { HGT2 } \\
\text { (cm) }\end{array}$ & $\begin{array}{l}\text { GCD } \\
(\mathrm{cm})\end{array}$ & DFL & DFR & $\begin{array}{l}\text { LOF } \\
(\mathrm{mm})\end{array}$ & $\begin{array}{l}\text { DOF } \\
(\mathrm{mm})\end{array}$ & TNF \\
\hline $1 \mathrm{x} 1$ & 1.45 & 1.07 & -0.47 & -0.63 & -2.14 & 1.34 & 0.38 & -2.66 \\
\hline $1 \times 2$ & 1.25 & 0.63 & -0.00 & -1.63 & -2.64 & 0.88 & -0.41 & 23.65 \\
\hline $1 \times 3$ & -1.74 & -0.96 & 2.23 & 0.87 & 2.86 & -1.26 & 0.33 & -3.66 \\
\hline $1 \times 4$ & -1.20 & 0.53 & 0.36 & -0.45 & -0.45 & -5.05 & -0.24 & 1.71 \\
\hline $1 \times 5$ & -0.85 & -0.26 & -0.95 & 1.83 & 4.97 & 3.02 & -0.55 & -7.40 \\
\hline $1 \times 6$ & -0.36 & -2.94 & -0.70 & 0.64 & -0.47 & -0.28 & 0.12 & -8.96 \\
\hline $2 \times 2$ & 0.00 & -2.55 & -0.35 & 1.37 & 2.36 & -1.89 & 0.50 & 1.46 \\
\hline $2 \times 3$ & -0.13 & 0.37 & -0.16 & -0.63 & 0.86 & 1.75 & 0.17 & -3.85 \\
\hline $2 \times 4$ & -0.08 & -0.15 & -0.17 & -0.44 & -0.45 & -0.61 & -0.73 & 0.52 \\
\hline $2 \times 5$ & -0.63 & 2.31 & -0.08 & 0.33 & -1.03 & 1.37 & -0.83 & -11.59 \\
\hline $2 \times 6$ & -0.40 & 1.93 & 1.12 & -0.35 & -1.47 & 0.39 & 0.80 & -11.65 \\
\hline $3 \times 3$ & 1.78 & -0.41 & -2.12 & 0.37 & 0.36 & -4.38 & -0.22 & -5.66 \\
\hline $3 \times 4$ & -0.57 & 0.42 & 0.12 & -0.44 & -1.95 & 2.33 & 0.62 & 10.21 \\
\hline $3 \times 5$ & 0.47 & 3.18 & 1.50 & 0.83 & -1.03 & 7.78 & -1.01 & 0.10 \\
\hline $3 \times 6$ & -1.58 & -3.05 & 0.55 & -1.35 & -1.47 & -1.83 & 0.33 & 8.54 \\
\hline $4 \times 4$ & 1.12 & -0.25 & -0.75 & 1.74 & 1.74 & -2.86 & 0.06 & -3.92 \\
\hline $4 \times 5$ & -1.07 & -2.40 & 1.30 & -1.98 & -1.34 & -0.14 & 1.06 & -3.52 \\
\hline $4 \times 6$ & 0.71 & 2.12 & -0.11 & -0.17 & 0.72 & 9.19 & -0.84 & -1.08 \\
\hline $5 \times 5$ & 1.07 & -1.33 & -0.92 & -0.70 & -0.92 & -6.35 & 0.97 & 10.37 \\
\hline $5 \times 6$ & -0.56 & -0.16 & 0.08 & 0.39 & 0.29 & 0.67 & -0.64 & 1.67 \\
\hline $6 \times 6$ & 0.85 & 1.05 & -0.47 & 0.42 & 1.20 & -4.07 & 0.11 & 5.74 \\
\hline DP (Sii-Sjj) & 0.54 & 1.38 & 1.49 & 0.68 & 1.09 & 1.56 & 0.37 & 5.64 \\
\hline DP (Sij-Sik) & 0.71 & 1.83 & 1.96 & 0.89 & 1.44 & 2.06 & 0.49 & 7.46 \\
\hline DP (Sij-Skl) & 0.66 & 1.69 & 1.82 & 0.83 & 1.33 & 1.91 & 0.45 & 6.91 \\
\hline
\end{tabular}

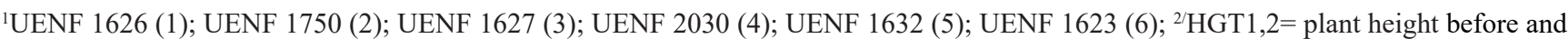
afterwards fruiting; $\mathrm{GCD}=$ canopy diameter; $\mathrm{DFL}=$ number of days to flourishing; $\mathrm{DFR}=$ days to fruiting; $\mathrm{LOF}=$ fruit length; $\mathrm{DOF}=$ fruit diameter; $\mathrm{TNF}=$ total number of fruits.

for HET1, and showed favorable results for HET2, such as: UENF $1626 \mathrm{x}$ UENF 1627 (-0.96); UENF $1626 \times$ X UENF 1632 (-0.26); UENF 1626 x UENF 1623 (-2.94); UENF $1750 \times$ X UENF 2030 (-0.15); UENF 1627 x UENF 1623 (-3.05); UENF $2030 \mathrm{x}$ UENF $1632(-2.40)$ and UENF $1632 \times$ UENF $1623(-0.16)$. In the same manner, it is highlighted that combinations that did not include parental UENF 1626 and UENF 1632 overcame the expectations concerning values of GCA.

Canopy diameter requires positive values of Ŝii, providing attractive visual effects as it presents more foliage, a desired trait for ornamental purposes. Thus, the best results were found in crossings UENF 1626 x UENF 1627 (2.23), UENF $1750 \times$ UENF 1623 (1.12); UENF 1627 x UENF 1632 (1.50) and UENF 2030 x UENF 1632 (1.30). Nevertheless, in accordance with the effect values of GCA, only the combinations UENF 1750 x UENF 1623 have both parents as superior.

Silva Neto et al. (2014) showed in their study the significance of plant structure and its aesthetical-visual harmony, considering plant height and canopy diameter important for ornamental purposes.

The best combinations concerning earliness values (negative values of Sii for DFL and DFR) were identified in hybrids UENF 1626 x UENF 1750
(-1.63 DFL and -2.64 DFR), UENF 1626 x UENF 2030 (-0.45 DFL and DFR), UENF $1750 \times$ UENF 2030 (-0.44 DFL and -0.5 DFR); UENF $1750 \times$ UENF 1623 (-0.35 DFL and -1.47 DFR), UENF 1627 x UENF 2030 (-0.44 DFL and -1.95 DFR), UENF $1627 \times$ UENF 1623 ( -1.35 DFL and -1.47 DFR) and UENF 2030 x UENF 1632 (-0.70 DFL and -0.92 DFR), with combinations resulted from parents UENF 1623, UENF 1632 and UENF 2030 expressing expected earliness results according to estimations of GCA.

Regarding LOF and DOF, the combinations with lower values of these characteristics, obtaining negative values of Ŝii, were the crossings UENF 
Table 5. Means ${ }^{1}$ and heterosis percentage compared to parent mean $(\mathrm{H})$ for eight characteristics evaluated in complete diallel without reciprocals, among six parents of Capsicum annuum. Campos dos Goytacazes, UENF, 2014.

\begin{tabular}{|c|c|c|c|c|c|c|c|c|}
\hline \multirow{2}{*}{ Genotypes $^{2}$} & \multicolumn{2}{|c|}{ HGT1 (cm) } & \multicolumn{2}{|c|}{ HGT2 (cm) } & \multicolumn{2}{|c|}{ GCD (cm) } & \multicolumn{2}{|c|}{ DFL } \\
\hline & Mean & $\mathrm{H}(\%)$ & Mean & $\mathbf{H}(\%)$ & Mean & H(\%) & Mean & $\mathbf{H}(\%)$ \\
\hline$\overline{1 \times 1}$ & $9.33 c$ & 0.00 & $19.26 \mathrm{~d}$ & 0.00 & $31.84 \mathrm{a}$ & 0.00 & $50.00 \mathrm{~b}$ & 0.00 \\
\hline $1 \times 2$ & $10.61 b$ & 5.20 & $21.13 \mathrm{c}$ & 6.92 & $34.45 \mathrm{a}$ & 1.17 & $49.00 \mathrm{~b}$ & -3.92 \\
\hline $1 \times 3$ & $8.40 \mathrm{c}$ & -28.94 & $23.05 \mathrm{c}$ & -1.89 & $34.79 \mathrm{a}$ & 10.74 & $52.00 \mathrm{a}$ & 1.96 \\
\hline $1 \times 4$ & $9.03 c$ & -22.73 & $22.05 \mathrm{c}$ & 0.59 & $34.17 \mathrm{a}$ & 2.96 & $50.00 \mathrm{~b}$ & -2.00 \\
\hline $1 \times 5$ & $6.77 \mathrm{~d}$ & -23.55 & $17.62 d$ & -0.69 & $31.82 \mathrm{a}$ & -0.77 & $52.00 \mathrm{a}$ & 5.15 \\
\hline $1 \times 6$ & $9.01 \mathrm{c}$ & -14.16 & $21.89 \mathrm{c}$ & -15.56 & $33.23 \mathrm{a}$ & -0.65 & $48.00 \mathrm{~b}$ & 1.57 \\
\hline $2 \times 2$ & $10.70 \mathrm{~b}$ & 0.00 & $20.16 \mathrm{c}$ & 0.00 & $35.46 \mathrm{a}$ & 0.00 & $51.00 \mathrm{a}$ & 0.00 \\
\hline $2 \times 3$ & $11.37 \mathrm{~b}$ & -8.42 & $24.21 \mathrm{c}$ & 8.03 & $36.00 \mathrm{a}$ & 3.14 & $50.00 \mathrm{a}$ & -2.91 \\
\hline $2 \times 4$ & $11.28 \mathrm{~b}$ & -5.65 & $23.40 \mathrm{c}$ & 5.75 & $34.40 \mathrm{a}$ & 1.09 & $49.00 \mathrm{~b}$ & -3.96 \\
\hline $2 \times 5$ & $8.18 \mathrm{c}$ & -12.33 & $22.28 \mathrm{c}$ & 22.67 & $35.15 \mathrm{a}$ & 1.63 & $49.00 \mathrm{~b}$ & 0.00 \\
\hline $2 \times 6$ & $10.50 \mathrm{~b}$ & -7.35 & $26.86 b$ & 10.16 & $31.95 \mathrm{a}$ & 4.24 & $47.00 \mathrm{c}$ & -2.59 \\
\hline $3 \times 3$ & $12.90 \mathrm{a}$ & 0.00 & $26.86 \mathrm{~b}$ & 0.00 & $33.10 \mathrm{a}$ & 0.00 & $51.00 \mathrm{a}$ & 0.00 \\
\hline $3 \times 4$ & $11.03 b$ & -15.55 & $24.72 \mathrm{c}$ & 3.09 & $35.46 \mathrm{a}$ & 4.71 & $49.00 \mathrm{~b}$ & -2.97 \\
\hline $3 \times 5$ & $9.44 \mathrm{c}$ & -8.69 & $25.60 \mathrm{~b}$ & 19.01 & $35.71 \mathrm{a}$ & 9.36 & $51.00 \mathrm{a}$ & 2.04 \\
\hline $3 \times 6$ & $10.01 \mathrm{~b}$ & -22.74 & $25.55 b$ & -11.68 & $36.71 \mathrm{a}$ & 5.36 & $47.00 \mathrm{c}$ & -3.63 \\
\hline $4 \times 4$ & $12.04 \mathrm{a}$ & 0.00 & $23.28 \mathrm{c}$ & 0.00 & $32.74 \mathrm{a}$ & 0.00 & $48.00 \mathrm{~b}$ & 0.00 \\
\hline $4 \times 5$ & $7.86 \mathrm{c}$ & -20.96 & $18.07 \mathrm{~d}$ & -8.00 & $33.60 \mathrm{a}$ & 6.55 & $46.00 \mathrm{c}$ & -5.21 \\
\hline $4 \times 6$ & $11.77 \mathrm{a}$ & -2.28 & $27.45 b$ & 6.25 & $35.88 \mathrm{a}$ & 1.44 & $46.00 \mathrm{c}$ & -2.64 \\
\hline $5 \times 5$ & $8.37 \mathrm{c}$ & 0.00 & $17.66 \mathrm{~d}$ & 0.00 & $31.06 \mathrm{a}$ & 0.00 & $47.00 \mathrm{c}$ & 0.00 \\
\hline $5 \times 6$ & - & - & - & - & - & - & - & - \\
\hline \multirow[t]{2}{*}{$6 \times 6$} & $11.79 \mathrm{a}$ & 0.00 & $31.19 \mathrm{a}$ & 0.00 & $35.81 \mathrm{a}$ & 2.29 & $44.00 \mathrm{~d}$ & 1.16 \\
\hline & \multicolumn{2}{|c|}{ DFR } & \multicolumn{2}{|c|}{ LOF (mm) } & \multicolumn{2}{|c|}{ DOF $(\mathrm{mm})$} & \multicolumn{2}{|c|}{ TNF } \\
\hline $1 \mathrm{x} 1$ & $25.00 \mathrm{c}$ & 0.00 & $18.78 \mathrm{e}$ & 0.00 & $10.91 \mathrm{e}$ & 0.00 & $76.00 \mathrm{c}$ & 0.00 \\
\hline $1 \times 2$ & $26.00 \mathrm{c}$ & -10.28 & $16.98 \mathrm{e}$ & 7.82 & $9.48 \mathrm{f}$ & -8.56 & $107.00 \mathrm{a}$ & 27.17 \\
\hline $1 \times 3$ & $31.00 \mathrm{a}$ & 14.28 & $30.13 \mathrm{c}$ & 0.86 & $10.12 \mathrm{e}$ & 2.31 & $62.00 \mathrm{~d}$ & 0.91 \\
\hline $1 \times 4$ & $25.00 \mathrm{c}$ & -1.03 & $26.58 \mathrm{~d}$ & -13.96 & $9.10 \mathrm{f}$ & -4.90 & $71.00 \mathrm{c}$ & 8.20 \\
\hline $1 \times 5$ & $30.00 \mathrm{~b}$ & 27.66 & $30.63 \mathrm{c}$ & 21.96 & $13.88 \mathrm{c}$ & -8.20 & $32.00 \mathrm{e}$ & -26.31 \\
\hline $1 \times 6$ & $24.00 \mathrm{~d}$ & 0.00 & $26.26 \mathrm{~d}$ & 4.33 & $12.81 \mathrm{~d}$ & -0.96 & $40.00 \mathrm{e}$ & -21.21 \\
\hline $2 \times 2$ & $29.00 \mathrm{~b}$ & 0.00 & $12.80 \mathrm{f}$ & 0.00 & $9.35 \mathrm{f}$ & 0.00 & $108.00 \mathrm{a}$ & 0.00 \\
\hline $2 \times 3$ & $28.00 \mathrm{~b}$ & -1.75 & $34.08 \mathrm{c}$ & 16.95 & $9.92 \mathrm{e}$ & 0.30 & $69.00 \mathrm{c}$ & -2.37 \\
\hline $2 \times 4$ & $25.00 \mathrm{c}$ & -9.43 & $29.33 d$ & 6.15 & $8.08 \mathrm{~g}$ & -11.45 & $85.00 \mathrm{~b}$ & 2.19 \\
\hline $2 \times 5$ & $25.00 \mathrm{c}$ & -6.79 & $29.07 d$ & 23.78 & $12.91 \mathrm{~d}$ & -10.89 & $47.00 \mathrm{e}$ & -28.45 \\
\hline $2 \times 6$ & $25.00 \mathrm{c}$ & -12.87 & $26.25 \mathrm{~d}$ & 14.60 & $12.64 d$ & 4.06 & $56.00 \mathrm{~d}$ & -22.34 \\
\hline $3 \times 3$ & $29.00 \mathrm{~b}$ & 0.00 & $45.89 \mathrm{~b}$ & 0.00 & $10.57 \mathrm{e}$ & 0.00 & $39.00 \mathrm{e}$ & 0.00 \\
\hline $3 \times 4$ & $24.00 \mathrm{~d}$ & -11.54 & $50.38 \mathrm{a}$ & 13.28 & $10.24 \mathrm{e}$ & 7.43 & $56.00 \mathrm{~d}$ & 32.96 \\
\hline $3 \times 5$ & $27.00 \mathrm{~b}$ & -2.97 & $52.23 \mathrm{a}$ & 33.52 & $13.73 \mathrm{c}$ & -9.26 & $25.00 \mathrm{f}$ & -8.26 \\
\hline $3 \times 6$ & $23.00 \mathrm{~d}$ & -9.09 & $41.10 \mathrm{~b}$ & 6.11 & $12.91 \mathrm{~d}$ & 3.02 & $45.00 \mathrm{e}$ & 25.00 \\
\hline $4 \times 4$ & $23.00 \mathrm{~d}$ & 0.00 & $42.87 \mathrm{~b}$ & 0.00 & $8.80 \mathrm{f}$ & 0.00 & $59.00 \mathrm{~d}$ & 0.00 \\
\hline $4 \times 5$ & $21.00 \mathrm{~d}$ & -7.53 & $43.49 \mathrm{~b}$ & 11.44 & $14.40 \mathrm{c}$ & 3.90 & $28.00 \mathrm{f}$ & -20.30 \\
\hline $4 \times 6$ & $22.00 \mathrm{~d}$ & -3.30 & $49.92 \mathrm{a}$ & 32.46 & $10.85 \mathrm{e}$ & -7.87 & $37.00 \mathrm{e}$ & -5.00 \\
\hline $5 \times 5$ & $23.00 \mathrm{~d}$ & 0.00 & $33.74 \mathrm{c}$ & 0.00 & $19.23 \mathrm{a}$ & 0.00 & $18.00 \mathrm{f}$ & 0.00 \\
\hline $5 \times 6$ & - & - & - & - & - & - & - & - \\
\hline $6 \times 6$ & $23.00 \mathrm{~d}$ & 0.71 & $32.43 \mathrm{c}$ & 0.00 & $14.76 \mathrm{c}$ & 0.00 & $29.00 \mathrm{f}$ & 0.0 \\
\hline
\end{tabular}

${ }^{1}$ Means followed by the same letter do not differ significantly by the Scott-Knott test, $0.05 \%$; ${ }^{2}$ UENF 1626 (1); UENF 1750 (2); UENF 1627 (3); UENF 2030 (4); UENF 1632 (5); UENF 1623 (6). ${ }^{2} \mathrm{HGT} 1.2=$ plant height before and afterwards fruiting; GCD= canopy diameter; DFL= number of days to flourishing; $\mathrm{DFR}=$ days to fruiting; $\mathrm{LOF}=$ fruit length; $\mathrm{DOF}=$ fruit diameter; $\mathrm{TNF}=$ total number of fruits. 
Figure 1. The hybrids UENF 1626 x UENF 1750, UENF 1750 x UENF 2030 and UENF 1626 x UENF 2030 recommended for cultivation with ornamental purposes. Campos dos Goytacazes, UENF, 2014.

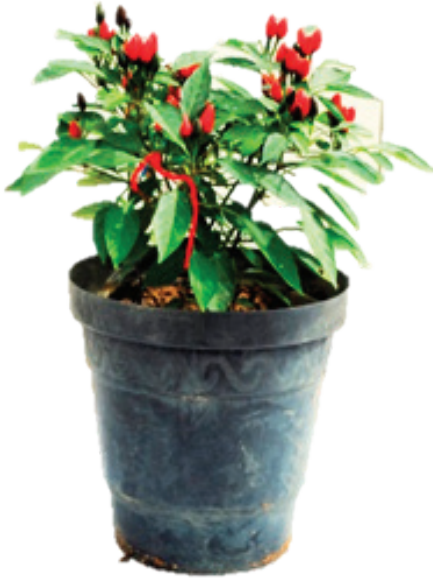

UENF1626 x UENF 1750

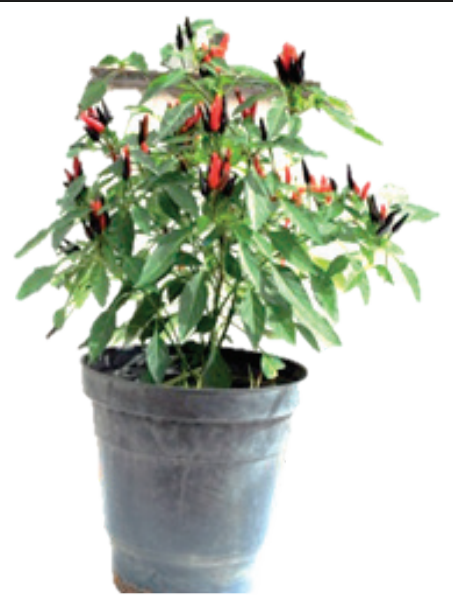

UENF1750 x UENF 2030

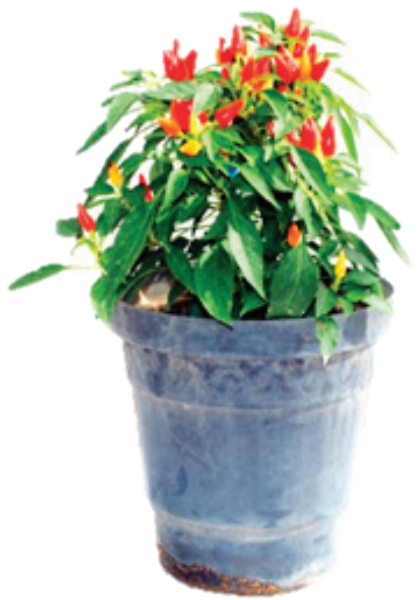

UENF1626 x UENF 2030
$1626 \times$ UENF 2030 (LOF -5.05 and DOF -0.24) and UENF $1750 \mathrm{x}$ UENF 2030 (LOF -0.61 and DOF -0.73); therefore, the parentals UENF 1626 and UENF 1750 were superior for GCA values. Concerning TNF, positive values of $\hat{\mathrm{S}} \underline{i \mathrm{i}}$ are appealing for ornamental character, which is present in the following combinations: UENF 1626 x UENF 1750 (23.65), UENF 1626 x UENF 2030 (1.46), UENF 1627 x UENF 2030 (10.21), UENF $1627 \mathrm{x}$ UENF 1623 (8.54) and UENF 1632 $x$ UENF 1623 (1.67). Exclusively the combinations UENF 1627 x UENF 1623 and UENF 1632 x UENF 1623 obtained non expected values in accordance with effects of general capacity of parental combination.

Silva et al. (2015) discussed plant earliness importance in ornamental chili peppers, considering that early plants are desirable to reduce producer costs and promptly meet consumer market expectations. These authors also reported the importance of small-sized fruits and in large quantity per plant, providing greater attractiveness for chili pepper plants.

\section{Scott-Knott grouping test of averages}

The grouping test of averages enabled identification of four classes for HET1, HET2, DFL and DFR; one class for GCD; seven classes for DOF and six classes for LOF and TNF (Table 5 ). These results suggest the presence of variability among the studied genotypes. The averages for HET1 varied from 6.77 to $12.90 \mathrm{~cm}$ while HET2 varied from 17.62 to $31.19 \mathrm{~cm}$. The highest plants in after-fruiting evaluation (HET2) were observed for UENF 1623 genitor while UENF 1626 genitor and UENF $1626 \mathrm{x}$ UENF 1632 hybrid produced smallersized plants. Melo et al. (2014) identified low accessions with heights varying from 19.75 to $31.50 \mathrm{~cm}$, when selecting plants with ornamental potential.

Regarding canopy diameter, there was no significant difference among treatments and values varied from 31.06 to $36.71 \mathrm{~cm}$. Days to fruiting varied from 44 to 52 days after transplanting, enabling a selection of early genotypes. Moreover, expressive differences among genotypes were found and values varied from 21 to 31 days. Early genotypes are compelling for producers to commercialize their product quickly (Patil \& Bhalekar, 2012; Silva et al., 2015), thereby reducing its production costs.

Fruit diameter had the greatest variation amplitude in averages, varying from $8.08 \mathrm{~cm}$ to $19.23 \mathrm{~cm}$, divided into seven classes. In sequence, fruit length and number of fruits per plant had also great amplitude of variation in averages, both composing six classes. Regarding fruit length, the variation was from 12.80 to $52.23 \mathrm{~cm}$, and number of fruits per plant varied from 18 to 108 fruits.

\section{Heterosis}

Heterosis varied from -28.94 (HET1) to $33.52 \%$ (LOF) (Table 5), demonstrating quite a few negative values, which indicates reduction of plant height, time to flourishing and fruiting, as well as fruit diameter and length. Such reductions are desirable for ornamental Capsicum breeding programs. Additionally, Blat et al. (2007), conducting studies in pepper hybrids with basis on heterosis estimation, found negative heterosis for plant height and according to these authors, medium heights are ideal for pepper plants. However, for ornamental purposes, small-sized plants are preferred for pot cultivation. Nascimento et al. (2010), analyzing combinatorial ability of pepper lineages, identified that the heterosis estimation varied considerably for four traits (productivity, fruit average mass, early production of fruits and plant height). Specifically for plant height, these authors observed variations of -18.23 to 15.07. Sousa \& Maluf (2003) observed values of heterosis varying from -93 to $55 \%$ for number of seeds per fruit 
in a chili pepper diallel (Capsicum chinense). Rodrigues et al. (2012) reported heterosis of approximately -24.78 for fruit dry mass (g) and 98.09 for number of fruits per plant, in a diallel of $C$. baccatum var. pendulum. Afroza et al. (2013), in studies of heterosis in $C$. annuum, found variations from -44.88 for number of fruits per plant to 106.69 for fruit yield per plant $(\mathrm{g})$. These investigations lead to the conclusion that data obtained in this study are in the limits of heterosis observed for studies with Capsicum. It is important to highlight that the genitors used in this diallel were indicated based on their agronomic performance and genetic divergence, according to Silva et al. (2015).

Concerning HET1, almost all hybrids had lower average compared to their parents and negative heterosis, except for UENF 1626 x UENF 1750 that obtained higher height average than parents and positive heterosis. Values of negative heterosis for height indicate smaller plants, ideal for pot cultivation. Nascimento et al. (2010), whose aim was to evaluate combining ability in pepper lineages, highlighted the importance of obtaining smallersized plants, identifying heterosis values up to -15.49. Regarding HET2, six hybrid combinations (UENF $1626 \mathrm{x}$ UENF 1627; UENF 1626 x UENF 1632; UENF 1626 x UENF 1623; UENF 1627 $x$ UENF 2030; UENF 1627 x UENF 1623 and UENF $2030 \times$ UENF 1632) presented lower values than their parents did; however, only UENF 1627 x UENF 2030 did not present negative heterosis.

Except for UENF 1626 x UENF 1623 and UENF $1750 \times$ UENF 1623 hybrids, all others presented GCD superior to their parents and positive heterosis. UENF 1626 x UENF 1632 hybrid presented negative heterosis $(-0.77)$ for this characteristic. On the other hand, UENF 1626 x UENF 1627 stood out with heterosis value of 10.74 . Rodrigues et al. (2012), evaluating hybrids of Capsicum baccatum, found positive values of heterosis for canopy diameter varying from 1.14 to $12.82 \mathrm{~cm}$.

Concerning DFL, five hybrids and two genitors (UENF 1750 x UENF 1623; UENF 1627 x UENF 1623; UENF 2030 x UENF 1632; UENF 2030 x UENF 1623; UENF 1632 and UENF 1623) had the lowest values, characterizing them as early for flourishing. In terms of DFR, five hybrids and three genitors (UENF 1626 x UENF 1623; UENF 1627 x UENF 2030; UENF 1627 x UENF 1623; UENF 2030 x UENF 1632; UENF 2030 x UENF 1623; UENF 2030; UENF 1632 and UENF 1623) showed the greatest earliness. Negative heterosis for DFL and DFR indicate reduced number of days to flourishing and fruiting, with the early genotypes acting as the most appealing for producers (Blat et al., 2007; Patil \& Bhalekar, 2012; Silva et al., 2015). Gomide et al. (2003) and Patil \& Bhalekar (2012) achieved negative heterosis $(-4.50$ to -75.76$)$ and $(-1.31$ to -17.61$)$ for earliness in peppers and chilies (Capsicum annuum), respectively.

Among the hybrids, the lowest LOF was registered for UENF $1626 \mathrm{x}$ UENF $1750(16.98 \mathrm{~cm})$ and the hybrid combination UENF 1626 x UENF 2030 obtained the greatest negative value of heterosis for this character. Still among hybrids, the greatest values of fruit length were observed for UENF 1627 $x$ UENF 2030, UENF 1627 x UENF 1632 and UENF 2030 x UENF 1623. In relation to fruit diameter, the hybrid UENF $1750 \times$ UENF 2030 was the one with the lowest average and heterosis with the greatest negative value.

In regards of TNF, UENF 1626 $\mathrm{x}$ UENF 1750 hybrid together with UENF 1750 genitor produced greater number of fruits, with more than 100 fruits per plant, although the greatest heterosis values were observed for UENF 1627 x UENF 2030 and UENF $1627 \times$ UENF 1623 hybrids (+32.96 and +25.00 , respectively). Positive heterosis for this character was observed only for six hybrids (UENF 1626 x UENF 1750; UENF 1626 x UENF 1627; UENF 1626 $x$ UENF 2030; UENF 1750 x UENF 2030; UENF 1627 x UENF 2030 and UENF 1627 x UENF 1623). Rodrigues et al. (2012) found values of positive heterosis from 3.89 to 37.19 for number of fruits in $C$. baccatum. It must be highlighted that small-sized fruits and in higher number are ideal for ornamental chili pepper production.
Aiming to develop new cultivars for ornamental chili pepper market, and considering a chili pepper ideotype proposed, which consists in small-sized plants (up to $30 \mathrm{~cm}$ ), precocious in days to flourishing and fruiting, and in high number of fruits per plant, the following hybrids could be recommended: UENF $1626 \mathrm{x}$ UENF 1750 and UENF $1750 \mathrm{x}$ UENF 2030 (Figure 1). Besides that, UENF 1626 x UENF 2030 hybrid can also be recommended as it attends parameters proposed for the ideotype, and presents satisfactory esthetical structure, although having a lower performance compared to hybrids previously cited in terms of fruits per plant.

\section{ACKNOWLEDGEMENTS}

The authors thank the FAPERJ for granting scholarships to the first author and for the research support.

\section{REFERENCES}

AFROZA, B; KHAN, SH; JABEEN, N; NARAYAN, S. 2013. Heterosis studies for yield and maturity traits in sweet pepper (Capsicum annuum L.). Annals of Agri-Bio Reserch 18: 368-370.

BLAT, SF; BRAZ, LT; ARRUDA, AS. 2007. Avaliação de híbridos duplos de pimentão. Horticultura Brasileira 25: 350-354.

CARDOSO, AII. 2005. Polinização manual em abobrinha: efeitos nas produções de frutos e de sementes. Horticultura Brasileira 23: 731-734.

CARVALHO, SIC; BIANCHETTI, LB; RIBEIRO, CSC; LOPES, CA. 2006. Pimentas do gênero Capsicum no Brasil. Brasília: Embrapa Hortaliças. p. 27.

CRUZ, CD. 2016. Genes Software-extended and integrated with the R, Matlab and Selegen. Acta Scientiarum 38: 547-552.

GODOY, MC; GODOY, AR; CARDOSO, AII. 2006. Influência do estádio de maturação da flor na produção de sementes de pimentão com polinização manual. Bragantia 65 : 83-87.

GOMIDE, ML; MALUF, WR; GOMES, LAA. 2003 Heterose e capacidade combinatória de linhagens de pimentão (Capsicum annuum L.). Ciência e Agrotecnologia 27: 1007-1015.

HASANUZZAMAN, M; HAKIM, MA; HANAFI, MM; SHUKOR-JURAIMI, A; ISLAM, MM; SHAMSUDDIN, AKM. 2013. Study of heterosis in Bangladesh Chili (Capsicum annuum L.) landraces. Agrociencia 47: 683-690.

IPGRI. 1995. Descriptores para Capsicum (Capsicum spp.). p.51 
MEDEIROS, AM; RODRIGUES, R; GONÇALVES, LSA; SUDRÉ, CP; OLIVEIRA, HS; SANTOS, MH. 2014. Gene effect and heterosis in Capsicum baccatum var. pendulum. Ciência Rural 44: 1031-1036.

MELO, LF; GOMES, RLF; SILVA, VB; MONTEIRO, ER; LOPES, ACA; PERON, AP. 2014. Potencial ornamental de acessos de pimenta. Ciência Rural 44: 2010-2015.

NASCIMENTO, IR; MALUF, WR; GONÇALVES, LD; FARIA, MV; RESENDE, JTV; NOGUEIRA, DW. 2010. Capacidade combinatória de linhagens de pimentão a partir de análise dialélica multivariada. Acta Scientiarum 32: 235-240.

NASCIMENTO， NFF； RÊGO， ER; NASCIMENTO, MF; BRUCKNER, CH; FINGER, FL; RÊGO, MM. 2014. Combining ability for yield and fruit quality in the pepper Capsicum annuum. Genetics and Molecular Research 13: 3237-3249.

NEITZKE, RS; BARBIERI, RL; RODRIGUES, WF; CORREA, IV; CARVALHO, FIF. 2010. Dissimilaridade genética entre acessos de pimenta com potencial ornamental. Horticultura Brasileira 28: 47-53.

NEVES, MF; PINTO, MJA; LIMA JUNIOR, JC; NAKATANI, JK; MONACO NETO, LC; LIMA, LACV; KALAKI, RB; CAMARGO,
RB. 2015. Mapeamento e Estratégias para a Cadeia de Flores no Brasil. 1. ed. São Paulo: OCESP. 132p.

PANDEY, V; CHURA, A; PANDEY, HK; MEEN, HSA; ARYA, MC; AHMED, Z. 2012. Diallel analysis for yield and yield attributing traits in Capsicum (Capsicum annuum L. var. grossum Sendt). Vegetable Science 39: 136-139.

PATIL, BT; BHALEKAR, MN; SHINDE, KG. 2012. Heterosis studies in chilli (Capsicum annuит L.) for earliness, growth and green fruit yield. Vegetable Science 39: 73-75.

RÊG, ER; NASCIMENTO, MF; NASCIMENTO, NFF; SANTOS, RMC; FORTUNATO, FLG; RÊGO, MM. 2012. Testing methods for producing self-pollinated fruits in ornamental peppers. Horticultura Brasileira 30: 669-672.

RÊGO, ER; RÊGO, MM; CRUZ, CD; FINGER, FL; CASALI, VWD. 2010. Phenotypic diversity, correlation and importance of variables for fruit quality and yield traits in Brazilian peppers (Capsicum baccatum). Genetic Resources and Crop Evolution 58: 909-918.

RÊGO, ER; RÊGO, MM; FINGER, FL; NASCIMENTO, NFF; NASCIMENTO, MF; SANTOS, RMC. 2013. Brazilian ornamental pepper breeding program: a consortium among universities, small farmers and government agencies. Breakthroughs in the Genetics and Breeding of Capsicum and Eggplant p.431.

RODRIGUES, R; GONÇALVES, LSA; BENTO, CS; SUDRÉ, CP; ROBAINA, RR; AMARAL JÚNIOR, AT. 2012. Combining ability and heterosis for agronomic traits in chili pepper. Horticultura Brasileira 30: 226-233.

SILVA, AR; CECON, PR; RÊGO, ER; NASCIMENTO, M. 2011. Avaliação do coeficiente de variação experimental para caracteres de frutos de pimenteiras. Ceres 58: 168-171.

SILVA, CQ; JASMIM, JM; SANTOS, JO; BENTO, CS; SUDRÉ, CP; RODRIGUES, R. 2015. Phenotyping and selecting parents for ornamental purposes in chili pepper accessions. Horticultura Brasileira 33: 66-73.

SILVA NETO, JJ; RÊGO, ER; NASCIMENTO, MF; FILHO, VALS; NETO, JXA; RÊGO, MM. 2014. Variabilidade em população base de pimenteiras ornamentais (Capsicum annuит L.). Ceres 61: 84-89.

SOUSA, JAD; MALUF, WR. 2003. Dialle1 analyses and estimation of genetic parameters of hot pepper (Capsicum chinense Jacq.). Scientia Agricola 60: 105-113 